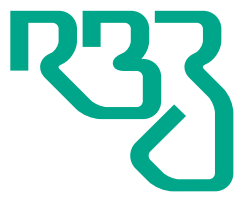

Revista

Brasileira de

Zootecnia

Brazilian Journal of Animal Science

ISSN 1806-9290

www.rbz.org.br

\section{Production and quality of the silage of corn intercropped with Paiaguas palisadegrass in different forage systems and maturity stages}

\author{
Wender Ferreira de Souza ${ }^{1^{*}}$ (iD), Kátia Aparecida de Pinho Costa ${ }^{1,2}$ (iD), Analu \\ Guarnieri $^{2}$, Eduardo da Costa Severiano ${ }^{2}$ (iD, Jessika Torres da Silva ${ }^{1}$ (iD, \\ Daniel Augusto Alves Teixeira $^{1}$ (iD), Suelen Soares Oliveira ${ }^{1}$ (iD), Mariana \\ Borges de Castro Dias ${ }^{2}$ iD \\ ${ }^{1}$ Instituto Federal Goiano, Programa de Pós-Graduação em Zootecnia, Rio Verde, GO, Brasil. \\ ${ }^{2}$ Instituto Federal Goiano, Programa de Pós-Graduação em Ciências Agrárias - Agronomia, \\ Rio Verde, GO, Brasil.
}

\begin{abstract}
The objective of this study was to evaluate dry matter production, fermentative parameters, and nutritional value of the silage of corn intercropped with Paiaguas palisadegrass in different forage systems and maturity stages, in the off-season. The experiment was carried out in a randomized block design, with four replications, in a $5 \times 3$ factorial arrangement consisting of five forage systems: corn monocropped; Paiaguas palisadegrass monocropped; corn intercropped with Paiaguas palisadegrass in the row, inter-row, and oversown; and three corn maturity stages (milky, soft dough, and hard dough with 80, 90, and 110 days after sowing, respectively). The results showed that the silage of corn intercropped with Paiaguas palisadegrass in the row and inter-row at the hard dough stage presented greater productivity per area and better fermentative and nutritional characteristics. They can, therefore, be recommended as suitable sowing systems for silage production. Silages produced from intercropping systems proved to be an alternative feed supply technique, allowing the intensification of production systems, maximizing nutrient production per area, in a sustainable manner.
\end{abstract}

Keywords: Brachiaria brizantha, crop-livestock integration, forage conservation, organic acids, Zea mays
Copyright: This is an open access article distributed under the terms of the Creative Commons Attribution License (http://creativecommons.org/licenses/by/4.0/) which permits unrestricted use, distribution, and reproduction in any medium, provided the original work is properly cited.

\section{(cc) BY}

\title{
Introduction
}

Scarcity of roughage and loss of forage nutritional value are obstacles to cattle production in the tropics, consequently, resulting in low animal performance. In this sense, the production of intercropping systems of annual crops with tropical forages enables to increase the availability of quality forage for livestock feed in a sustainable way in the off-season, besides the benefits to the system, with recovery/ renewal of degraded pastures, quality, especially in the off-season, where there is low production and quality of forage (Costa et al., 2018).

In addition, the future supply of food for the growing population demand will be based on gains in productivity or occupation/recovery of agricultural areas in tropical regions, consequently, considering the mitigation of greenhouse gases, carbon sequestration, and production diversification.

Recently, a new crop-livestock integration system, called the Santa Ana System, was developed, mainly for cattle ranchers who need to recover pastures and at the same time produce silage (Embrapa, 2016). 
Among the forages indicated for silage production, corn crop is the most traditional and has been expanded in the last years during the off-season in crop-livestock integration systems (Garcia et al., 2013). Thus, corn is widely used for silage, because it presents great chemical and nutritional quality, high dry matter (DM) production per unit area, easy mechanical harvesting, good patterns of microbial fermentation, and high energy value (Carvalho et al., 2016).

Besides corn, among the crops available or recommended for ensiling, grasses of the genus Brachiaria have aroused interest and have been widely used, with positive results (Costa et al., 2011; Epifanio et al., 2014). Among these grasses, Brachiaria brizantha cv. BRS Paiaguás was released to meet the requirements of different production systems (Euclides et al., 2016).

However, high moisture damages the production of quality tropical grass silage due to multiplication of undesirable bacteria and production of effluents (Rabelo et al., 2014). Therefore, strategies are required for adequate preparation of silage, prioritizing the suitable stage of maturity (Santos et al., 2010).

Given the above reasons, the objective of this research was to evaluate DM production, fermentative parameters, and nutritional value of the silage of corn intercropped with Paiaguas palisadegrass in different forage systems and maturity stages, in the off-season. The hypothesis is that corn intercropped with Paiaguas palisadegrass increases the production of ensiled mass and contributes to the improvement of silage quality by changing the crude protein concentration. In addition, the hard dough stage may be the most suitable to achieve better fermentative and nutritive characteristics of the silage.

\section{Material and Methods}

The study was performed in Rio Verde, GO, Brazil $\left(17^{\circ} 48^{\prime} \mathrm{S}\right.$; $50^{\circ} 55^{\prime} \mathrm{W}$; $748 \mathrm{~m}$ altitude), from January to July 2015, in a distroferric red latosol (Oxisol) (Santos et al., 2013), with physical-chemical characterization at the $0-20 \mathrm{~cm}$ layer as follows: 580,140 , and $280 \mathrm{~g} \mathrm{~kg}^{-1}$ of clay, silt, and sand, respectively; $\mathrm{pH}$ in $\mathrm{CaCl}_{2}$ : 4.93; Ca: 2.59; $\mathrm{Mg}$ : 1.10; $\mathrm{Al}$ : 0.10; $\mathrm{Al}+\mathrm{H}$ : 5.9; $\mathrm{K}: 0.20 ; \mathrm{CEC}, 9.74 \mathrm{in} \mathrm{cmol}_{\mathrm{c}} \mathrm{dm}^{-3}$; $\mathrm{V}_{1}, 39.93 \%$; $\mathrm{P}$ (Mehlich): 1.65; Cu: 3.05; Zn: 4.30; Fe: $32.5 \mathrm{in} \mathrm{mg} \mathrm{dm}{ }^{-3}$; and organic matter: $25.6 \mathrm{~g} \mathrm{~kg}^{-1}$.

The experiment was conducted in a randomized block design, with four replications in a $5 \times 3$ factorial arrangement consisting of five forage systems: corn monocropped; Paiaguas palisadegrass monocropped; corn intercropped with Paiaguas palisadegrass in the row, inter-row, and oversown; and three corn maturity stages (milky, soft dough, and hard dough), totaling 60 experimental plots. The corn hybrid used was the dual-purpose hybrid AS 1581, for grain and silage production.

The dimensions of each experimental plot was $4 \times 4 \mathrm{~m}$, totaling $16 \mathrm{~m}^{2}$ area. Thirty days before sowing, 2 ton ha ${ }^{-1}$ of limestone filler was applied, aiming to increase base saturation to $60 \%$. Sowing was performed on February 11, 2015 with the use of $240 \mathrm{~kg} \mathrm{P}_{2} \mathrm{O}_{5} \mathrm{ha}^{-1}$ and $20 \mathrm{~kg}$ FTE BR $12 \mathrm{ha}^{-1}$ according to soil analysis and crop requirements.

In monocropping and intercropping systems, corn was sown at 3-cm depth. Paiaguas palisadegrass in row planting was sown at $6-\mathrm{cm}$ depth; in the inter-row, at $0.25 \mathrm{~m}$ from the corn row; and in the oversown, the Paiaguas palisadegrass was sown 10 days after sowing (DAS) corn between rows at $0.25 \mathrm{~m}$.

Two weeks after seedling emergence, thinning was carried out to keep a stand of 60,000 corn plants $\mathrm{ha}^{-1}$. Hand weeding was performed weekly up to 50 days after emergence to control weeds in the post-emergence period, and no herbicide was applied to suppress the growth of Paiaguas palisadegrass. Phytosanitary treatments were carried out whenever necessary and in accordance with the recommendations.

When corn plants were at the developmental stage of three and six fully developed leaves, fertilization was performed by applying $150 \mathrm{~kg} \mathrm{~N} \mathrm{ha}^{-1}$ and $75 \mathrm{~kg} \mathrm{~K}_{2} \mathrm{O} \mathrm{ha}{ }^{-1}$ as urea and potassium chloride, respectively, in all forage systems, in two applications.

R. Bras. Zootec., 48:e20180222, 2019 
Forages were harvested at 80,90 , and 110 DAS of corn for ensiling, referring to maturity stages of corn: milky, soft dough, and hard dough, respectively. For the evaluation of DM production and proportion of ensiled material, we collected whole plants of corn and Paiaguas palisadegrass at $20 \mathrm{~cm}$ from the ground. Then, the material was weighed and the proportion of corn and Paiaguas palisadegrass was determined for all forage systems (Table 1). Afterwards, a portion of the material was oven-dried at $55{ }^{\circ} \mathrm{C}$ to constant weight, with subsequent dry weight determination and conversion into $\mathrm{kg} \mathrm{ha}^{-1}$.

For making silage, another subsample was ground in a stationary silage machine to particles of approximately $10 \mathrm{~mm}$ and stored in experimental PVC silos measuring $10 \mathrm{~cm}$ in diameter and $40 \mathrm{~cm}$ in length. The mean density of the silos was $558.12 \pm 24.20 \mathrm{~kg} \mathrm{dm}^{-3}$, for of all forage systems. Subsequently, the material was compacted with an iron pendulum, closed with PVC caps and sealed with adhesive tape to prevent the entry of air. Then, the experimental silos were kept in a roofed area at room temperature.

Silos were opened after 50 days of fermentation. The top and bottom portion of silage from each silo was discarded. The central portion was homogenized and placed on plastic trays. Part of the fresh silage after opening the silos was separated for analysis of $\mathrm{pH}$ and buffering capacity (eq.mg HCL $\left.100 \mathrm{~g}^{-1} \mathrm{DM}\right)$, using the method described by Silva and Queiroz (2002).

After this procedure, a sample of silage was taken and divided into two parts. The first was packed in plastic bags and frozen. For the determination of ammonia nitrogen $\left(\mathrm{N}-\mathrm{NH}_{3} \mathrm{~g} \mathrm{~kg}^{-1} \mathrm{~N}\right)$, the samples were thawed for juice extraction (Bolsen et al., 1992). The organic acids were determined in a Shimadzu, SPD-10A VP, high-performance liquid chromatography (HPLC), coupled to ultraviolet detector (UV), at a wavelength of $210 \mathrm{~nm}$, according to Kung and Shaver (2001). The other part of the silage with approximately $500 \mathrm{~g}$ was weighed and taken to a forced-ventilation oven at $55{ }^{\circ} \mathrm{C}$ for $72 \mathrm{~h}$, and then ground in a Wiley mill with a 1-mm sieve and stored in plastic containers.

The chemical analysis was performed to determine DM, mineral matter (MM), ether extract (EE) according to AOAC (1990); crude protein (CP) was obtained by determination of total $\mathrm{N}$ using the micro-Kjeldahl technique and the fixed conversion factor (6.25) (AOAC, 1990). Neutral detergent fiber (NDF) was determined according to Mertens (2002); acid detergent fiber (ADF), according to AOAC (1990); and lignin, according to Van Soest and Robertson (1985). Total digestible nutrients (NDT) were obtained using the equation (\% TDN $=105.2-0.68[\% \mathrm{NDF}]$ ) proposed by Chandler (1990). For in vitro DM digestibility (IVDMD), we adopted the technique described by Tilley and Terry (1963), adapted for artificial rumen developed by ANKON ${ }^{\circledR}$ using the Daisy incubator from Ankom Technology.

Chemical analyses were carried out for fresh corn and Paiaguas palisadegrass monocropped and intercropped in different forage systems, prior to ensiling, according to the methodologies described above (Table 2).

Table 1 - Proportion (\%) of the ensiled material of forages in different forage systems and maturity stages

\begin{tabular}{|c|c|c|c|c|c|c|}
\hline \multirow{3}{*}{ Forage system } & \multicolumn{6}{|c|}{ Maturity stage } \\
\hline & \multicolumn{2}{|c|}{ Milky } & \multicolumn{2}{|c|}{ Soft dough } & \multicolumn{2}{|c|}{ Hard dough } \\
\hline & $\mathrm{C}$ & $\mathrm{P}$ & $\mathrm{C}$ & $\mathrm{P}$ & $\mathrm{C}$ & $\mathrm{P}$ \\
\hline Monocropped corn & 100 & 0 & 100 & 0 & 100 & 0 \\
\hline Monocropped Paiaguas palisadegrass & 0 & 100 & 0 & 100 & 0 & 100 \\
\hline Row corn $\times$ Paiaguas palisadegrass & 82.22 & 17.77 & 77.33 & 22.66 & 74.08 & 25.91 \\
\hline Inter-row corn $\times$ Paiaguas palisadegrass & 81.80 & 18.19 & 74.57 & 25.42 & 73.88 & 26.12 \\
\hline Oversown corn $\times$ Paiaguas palisadegrass & 90.08 & 9.92 & 89.74 & 10.26 & 89.12 & 10.88 \\
\hline
\end{tabular}

C - corn; P - Paiaguas palisadegrass. 
Table 2 - Chemical composition of corn and Paiaguas palisadegrass monocropped and intercropped under different forage systems

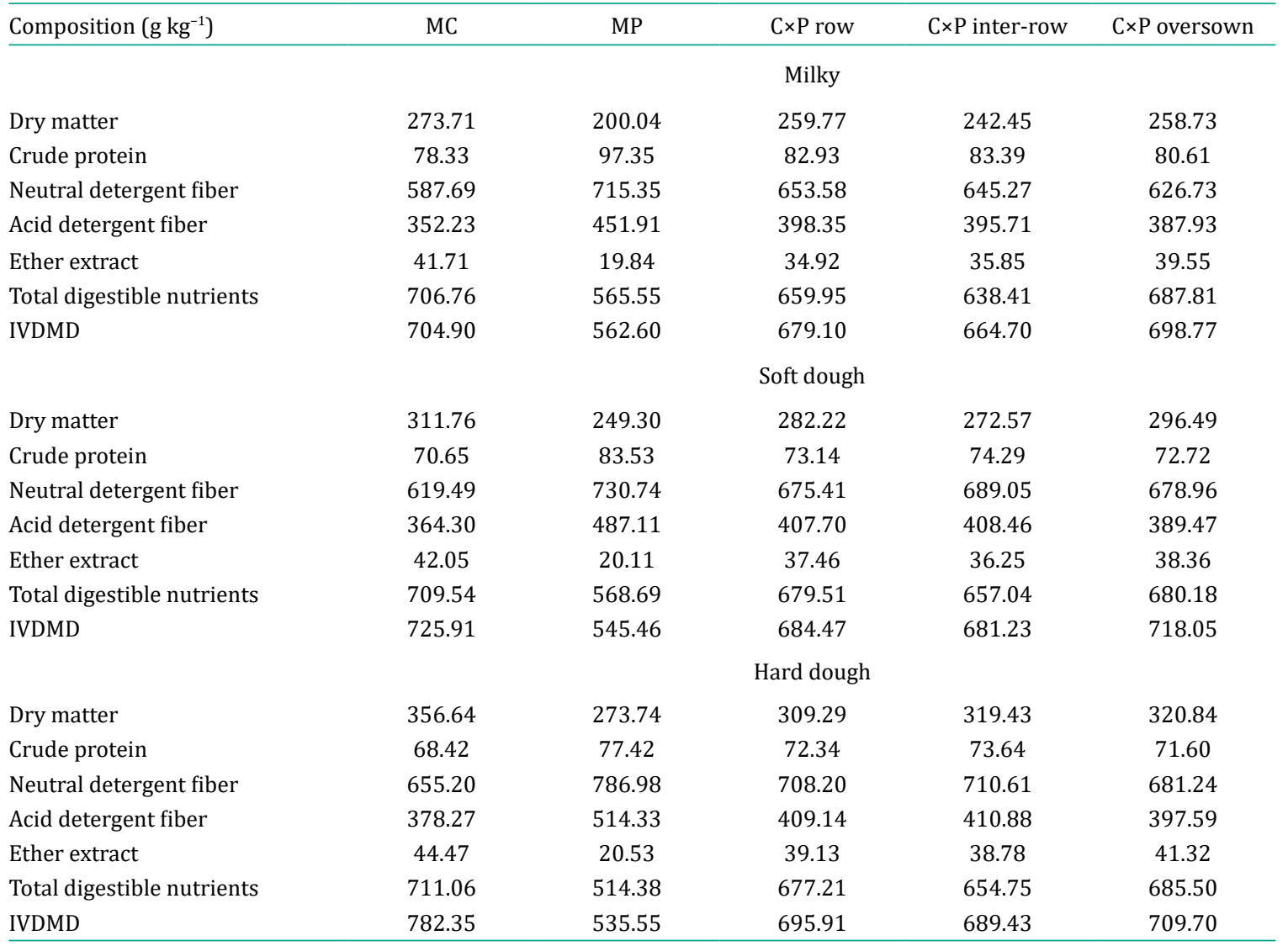

MC - monocropped corn; MP - monocropped Paiaguas palisadegrass; $\mathrm{C} \times \mathrm{P}$ row - corn intercropped with Paiaguas palisadegrass in the row; $\mathrm{C} \times \mathrm{P}$ inter-row - corn intercropped with Paiaguas palisadegrass inter-row; $\mathrm{C} \times \mathrm{P}$ oversown - corn intercropped with Paiaguas palisadegrass oversown; IVDMD - in vitro dry matter digestibility.

Data were subjected to analysis of variance, according to the following mathematical model:

$$
Y i j k=\mu+B i+C j+(B C) i j+R k+\varepsilon i j k,
$$

in which Yijk = observed value for the variable under study for the effect of block in combination with forage systems and maturity stages, $\mu=$ mean of the observations, $\mathrm{Bi}=$ effect of forage systems in the observed value Yijk, Cj = maturity stages in the observed value Yijk, (BC)ij = interaction effect of forage systems and maturity stages, $\mathrm{Rk}=$ block effect in the observation Yijk, and $\varepsilon \mathrm{ij}=$ random residual error of the observation Yijk.

The results were tested by analysis of variance, using the R program (version R-3.1.1) (2014) through the ExpDes package (Ferreira et al., 2014), and Tukey's test for comparison of means. Probability level of $5 \%$ was considered significant to test.

\section{Results}

When evaluating the DM production (Table 3), fermentative characteristics of silages (buffer capacity and $\mathrm{NH}_{3}-\mathrm{N}$ ), organic acids (lactic, acetic, propionic, and butyric acids), and DM concentration, there was a significant interaction $(\mathrm{P}<0.05)$ between forage systems and maturity stages (Tables 3 and 4 ). However, for the $\mathrm{pH}$ value, there was a significant effect $(\mathrm{P}<0.05)$ isolated for forage systems and maturity stages (Table 4). 
For forage systems, corn intercropped with Paiaguas palisadegrass in the row and inter-row presented greater dry mass production values than in the monocropping and overseeding systems, for all maturity stages.

Comparing maturity stages, for corn monocropped and intercropped in all sowing modes, the DM production was similar betwen milky and soft dough stages, differing from the hard dough stage, which presented greater productivity.

The silage of monocropped Paiaguas palisadegrass presented greater buffering capacity $(\mathrm{P}<0.05)$ compared with silages of the other systems for all maturity stages. There was a reduction in buffering capacity at the hard dough stage for monocropped and intercropped corn (Table 4).

The greatest values of $\mathrm{pH}$ of silages were obtained in silages of monocropped Paiaguas palisadegrass $(\mathrm{P}<0.05)$ in all forage systems and maturity stages (Table 4$)$. For the maturity stages, only the Paiaguas palisadegrass silage was influenced $(\mathrm{P}<0.05)$, with a greater $\mathrm{pH}$ value at the milky stage of corn. However, for monocropped and intercropped corn, the $\mathrm{pH}$ values were similar $(\mathrm{P}<0.05)$ between maturity stages.

Silages of monocropped and intercropped corn showed reductions in $\mathrm{NH}_{3}-\mathrm{N}$ concentration (Table 4). In relation to maturity stages, only the Paiaguas palisadegrass silage harvested at the milky stage of corn was significantly different $(\mathrm{P}<0.05)$ from the other stages (Table 4).

For the DM concentration of the forage systems, the silage of monocropped Paiaguas palisadegrass presented the lowest value, differing $(\mathrm{P}<0.05)$ from monocropped corn silage, in all maturity stages (Table 4). When comparing the DM concentrations between the stages, the silages of all forage systems, with the advancement of maturity stage, undergo morphological changes, which allow to check in a simple way the most appropriate moment to the ensiling process.

The silage of monocropped Paiaguas palisadegrass showed higher levels of acetic, propionic, and butyric acids in all maturity stages (Table 5). In addition, monocropped corn silage presented greater concentration of lactic acid $(\mathrm{P}<0.05)$, followed by silages of the intercropping systems.

Concerning maturity stages, for lactic acid concentration, there was no significant effect $(P>0.05)$ on monocropped Paiaguas palisadegrass silage, showing similar results in the three stages. Nevertheless, for silages of monocropped and intercropped corn, the greatest concentrations of lactic acid were obtained at the hard dough stage. Considering maturity stages, in all forage systems, the hard dough stage had the lowest concentrations of propionic and butyric acids (Table 5).

As for NDF and ADF concentration, the lowest values were found in monocropped corn silage, followed by the silages of the intercropping systems (Table 6). In relation to maturity stages (Table 6), there was an increase in NDF and ADF in all forage systems at the soft dough and hard dough stages.

Table 3 - Dry matter production of the ensiled material (ton ha ${ }^{-1}$ ) of forages in the different systems and maturity stages of corn

\begin{tabular}{lccc}
\hline \multirow{2}{*}{ Forage system } & \multicolumn{3}{c}{ Maturity stage } \\
\cline { 2 - 4 } Monocropped corn & Milky & Soft dough & Hard dough \\
Monocropped Paiaguas palisadegrass & $16.53 \mathrm{Bb}$ & $18.67 \mathrm{Bb}$ & $22.09 \mathrm{Ba}$ \\
Row corn $\times$ Paiaguas palisadegrass & $6.96 \mathrm{Cb}$ & $8.79 \mathrm{Ca}$ & $9.09 \mathrm{Ca}$ \\
Inter-row corn $\times$ Paiaguas palisadegrass & $19.01 \mathrm{Ab}$ & $20.76 \mathrm{Ab}$ & $27.97 \mathrm{Aa}$ \\
Oversown corn $\times$ Paiaguas palisadegrass & $19.69 \mathrm{Ab}$ & $21.34 \mathrm{Ab}$ & $29.46 \mathrm{Aa}$ \\
CV (\%) & $16.88 \mathrm{Bb}$ & $17.88 \mathrm{Bb}$ & $23.83 \mathrm{Ba}$ \\
P-value (forage system) & & 7.33 & 0.0012 \\
P-value (maturity stage) & & 0.0000 & \\
\hline
\end{tabular}

Mean values followed by different uppercase letters in the same column (forage systems) and lowercase letters in the same row (maturity stages) are significantly different by Tukey's test at $5 \%$ probability. 
In all forage systems, the lignin concentration was greater $(\mathrm{P}<0.05)$ in silages of monocropped Paiaguas palisadegrass (Table 6). For the maturity stages, the lowest lignin concentration was obtained at the milky stage in all forage systems, differing $(\mathrm{P}<0.05)$ from the soft dough and hard dough stages, which presented similar results (Table 6).

For CP, TDN, and IVDMD, there was influence $(\mathrm{P}<0.05)$ of forage systems and maturity stages, as well as the interaction of these factors (Table 7). However, for EE concentration, there was only a significant effect $(\mathrm{P}<0.05)$ of forage systems.

The lowest $\mathrm{CP}$ concentration of forage systems were obtained in monocropped corn silages, followed by the intercropping systems, in all maturity stages (Table 7). In relation to maturity stages, there was

Table 4 - Fermentative characteristics of silages in the different forage systems and maturity stages of corn

\begin{tabular}{|c|c|c|c|}
\hline \multirow{2}{*}{ Forage system } & \multicolumn{3}{|c|}{ Maturity stage } \\
\hline & Milky & Soft dough & Hard dough \\
\hline & \multicolumn{3}{|c|}{ Buffer capacity (eq.mg g ${ }^{-1} \mathrm{DM}$ ) } \\
\hline Monocropped corn & $65.41 \mathrm{Ca}$ & $57.92 \mathrm{Ca}$ & $53.38 \mathrm{Cb}$ \\
\hline Monocropped Paiaguas palisadegrass & $202.3 \mathrm{Aa}$ & 211.66 Aa & $231.94 \mathrm{Aa}$ \\
\hline Row corn $\times$ Paiaguas palisadegrass & 115.72Ba & $107.90 \mathrm{Ba}$ & $98.60 \mathrm{Bb}$ \\
\hline Inter-row corn $\times$ Paiaguas palisadegrass & $115.48 \mathrm{Ba}$ & $116.54 \mathrm{Ba}$ & $89.72 \mathrm{Bb}$ \\
\hline Oversown corn $\times$ Paiaguas palisadegrass & $91.60 \mathrm{BCa}$ & 89.91BCa & $81.93 \mathrm{Bb}$ \\
\hline $\mathrm{CV}(\%)$ & & 13.20 & \\
\hline P-value (forage system) & & 0.0000 & \\
\hline \multirow[t]{2}{*}{ P-value (maturity stage) } & & 0.0374 & \\
\hline & & $\mathrm{pH}$ & \\
\hline Monocropped corn & 3.83Ba & 3.69Ba & 3.61Ca \\
\hline Monocropped Paiaguas palisadegrass & 4.61Aa & 4.39Aab & $4.28 \mathrm{Ab}$ \\
\hline Row corn $\times$ Paiaguas palisadegrass & 3.94Ba & $3.96 \mathrm{Ba}$ & 3.93Ba \\
\hline Inter-row corn $\times$ Paiaguas palisadegrass & $4.06 \mathrm{Ba}$ & $3.94 \mathrm{Ba}$ & $3.91 \mathrm{Ba}$ \\
\hline Oversown corn $\times$ Paiaguas palisadegrass & 3.93Ba & 3.72Ba & $3.75 \mathrm{Ca}$ \\
\hline $\mathrm{CV}(\%)$ & & 4.18 & \\
\hline P-value (forage system) & & 0.0000 & \\
\hline \multirow[t]{2}{*}{ P-value (maturity stage) } & & 0.0316 & \\
\hline & \multicolumn{3}{|c|}{$\mathrm{N}-\mathrm{NH}_{3}\left(\mathrm{~g} \mathrm{~kg}^{-1} \mathrm{~N}\right)$} \\
\hline Monocropped corn & $24.72 \mathrm{Ba}$ & $23.40 \mathrm{Ba}$ & $23.68 \mathrm{Aa}$ \\
\hline Monocropped Paiaguas palisadegrass & $52.09 \mathrm{Aa}$ & $42.17 \mathrm{Ab}$ & $34.08 \mathrm{Ab}$ \\
\hline Row corn $\times$ Paiaguas palisadegrass & $24.30 \mathrm{Ba}$ & $22.47 \mathrm{Ba}$ & $27.89 \mathrm{Aa}$ \\
\hline Inter-row corn $\times$ Paiaguas palisadegrass & $29.10 \mathrm{Ba}$ & $24.37 \mathrm{Ba}$ & $25.77 \mathrm{Aa}$ \\
\hline Oversown corn $\times$ Paiaguas palisadegrass & $26.05 \mathrm{Ba}$ & $21.25 \mathrm{Ba}$ & $22.68 \mathrm{Aa}$ \\
\hline $\mathrm{CV}(\%)$ & & 19.17 & \\
\hline P-value (forage system) & & 0.0000 & \\
\hline \multirow[t]{2}{*}{ P-value (maturity stage) } & & 0.0419 & \\
\hline & \multicolumn{3}{|c|}{ Dry matter $\left(\mathrm{g} \mathrm{kg}^{-1}\right)$} \\
\hline Monocropped corn & 278.18Ac & $315.81 \mathrm{Ab}$ & $356.50 \mathrm{Aa}$ \\
\hline Monocropped Paiaguas palisadegrass & $206.27 \mathrm{Bb}$ & 249.39Bab & $276.70 \mathrm{Ba}$ \\
\hline Row corn $\times$ Paiaguas palisadegrass & $233.09 \mathrm{ABc}$ & $289.36 \mathrm{ABb}$ & $313.28 \mathrm{ABa}$ \\
\hline Inter-row corn $\times$ Paiaguas palisadegrass & $235.81 \mathrm{ABc}$ & $289.47 \mathrm{ABb}$ & 308.10ABa \\
\hline Oversown corn $\times$ Paiaguas palisadegrass & $249.45 \mathrm{ABc}$ & $299.83 \mathrm{ABb}$ & $323.02 \mathrm{ABa}$ \\
\hline $\mathrm{CV}(\%)$ & & 4.82 & \\
\hline P-value (forage system) & & 0.0012 & \\
\hline P-value (maturity stage) & & 0.0000 & \\
\hline
\end{tabular}

Mean values followed by different uppercase letters in the same column (forage systems) and lowercase letters in the same row (maturity stages) are significantly different by Tukey's test at $5 \%$ probability. 
a reduction in CP levels only in the silage of monocropped Paiaguas palisadegrass, with a decrease in concentration in the soft dough and hard dough maturity stages.

For the concentration of EE and TDN, monocropped corn silage presented the greatest values in all forage systems. Nevertheless, for maturity stages, EE and TDN values were similar ( $>>0.05)$ (Table 7).

Regarding IVDMD, monocropped corn silage presented greater results, followed by the intercropping systems in all forage systems. For the maturity stages, monocropped Paiaguas palisadegrass silage showed similar values $(\mathrm{P}>0.05)$ between the stages. However, for monocropeed and intercropped corn, only the milky stage was significantly different $(\mathrm{P}<0.05)$ from hard dough stage, which had the lowest value (Table 7).

Table 5 - Concentration of organic acids of silages in different forage systems and maturity stage of corn

\begin{tabular}{|c|c|c|c|}
\hline \multirow{2}{*}{ Forage system } & \multicolumn{3}{|c|}{ Maturity stage } \\
\hline & Milky & Soft dough & Hard dough \\
\hline & \multicolumn{3}{|c|}{ Lactic acid $\left(\mathrm{g} \mathrm{kg}^{-1} \mathrm{DM}\right)$} \\
\hline Monocropped corn & $55.88 \mathrm{Ab}$ & $61.72 \mathrm{Ab}$ & $73.20 \mathrm{Aa}$ \\
\hline Monocropped Paiaguas palisadegrass & 20.42Da & $19.25 \mathrm{Ca}$ & $19.93 \mathrm{Da}$ \\
\hline Row corn $\times$ Paiaguas palisadegrass & $34.93 \mathrm{Cb}$ & $41.58 \mathrm{Bb}$ & $55.56 \mathrm{Ca}$ \\
\hline Inter-row corn $\times$ Paiaguas palisadegrass & $36.77 \mathrm{Cb}$ & $42.27 \mathrm{Ba}$ & $48.74 \mathrm{Ca}$ \\
\hline Oversown corn $\times$ Paiaguas palisadegrass & $44.28 \mathrm{Bb}$ & $49.21 \mathrm{Bb}$ & $60.47 \mathrm{Ba}$ \\
\hline CV (\%) & & 10.39 & \\
\hline P-value (forage system) & & 0.0018 & \\
\hline \multirow[t]{2}{*}{ P-value (maturity stage) } & & 0.0000 & \\
\hline & \multicolumn{3}{|c|}{ Acetic acid $\left(\mathrm{g} \mathrm{kg}^{-1} \mathrm{DM}\right)$} \\
\hline Monocropped corn & $4.35 \mathrm{Ca}$ & $4.60 \mathrm{Ba}$ & $2.63 \mathrm{Bb}$ \\
\hline Monocropped Paiaguas palisadegrass & 9.21Aa & $6.48 \mathrm{Ab}$ & $5.55 \mathrm{Ab}$ \\
\hline Row corn $\times$ Paiaguas palisadegrass & $6.47 \mathrm{Ba}$ & $5.21 \mathrm{Ba}$ & $3.10 \mathrm{Bb}$ \\
\hline Inter-row corn $\times$ Paiaguas palisadegrass & $6.62 \mathrm{Ba}$ & $4.60 \mathrm{Bb}$ & $2.49 \mathrm{Bc}$ \\
\hline Oversown corn $\times$ Paiaguas palisadegrass & $6.40 \mathrm{Ba}$ & $4.49 \mathrm{Bb}$ & $2.62 \mathrm{Bc}$ \\
\hline $\mathrm{CV}(\%)$ & & 14.24 & \\
\hline P-value (forage system) & & 0.0012 & \\
\hline \multirow[t]{2}{*}{ P-value (maturity stage) } & & 0.0000 & \\
\hline & \multicolumn{3}{|c|}{ Propionic acid ( $\left.\mathrm{g} \mathrm{kg}^{-1} \mathrm{DM}\right)$} \\
\hline Monocropped corn & $3.44 \mathrm{Ba}$ & $2.11 \mathrm{Bb}$ & $1.31 \mathrm{Bc}$ \\
\hline Monocropped Paiaguas palisadegrass & 3.91Aa & $2.92 \mathrm{Ab}$ & $2.07 \mathrm{Ac}$ \\
\hline Row corn $\times$ Paiaguas palisadegrass & $3.50 \mathrm{Ba}$ & $2.38 \mathrm{Bb}$ & $1.48 \mathrm{Bc}$ \\
\hline Inter-row corn $\times$ Paiaguas palisadegrass & $3.58 \mathrm{Ba}$ & $2.41 \mathrm{Bb}$ & $1.51 \mathrm{Bc}$ \\
\hline Oversown corn $\times$ Paiaguas palisadegrass & $3.48 \mathrm{Ba}$ & $2.29 \mathrm{Bb}$ & $1.46 \mathrm{Bb}$ \\
\hline CV (\%) & & 10.12 & \\
\hline P-value (forage system) & & 0.0377 & \\
\hline \multirow[t]{2}{*}{ P-value (maturity stage) } & & 0.0000 & \\
\hline & \multicolumn{3}{|c|}{ Butyric acid $\left(\mathrm{g} \mathrm{kg}^{-1} \mathrm{DM}\right)$} \\
\hline Monocropped corn & $0.23 \mathrm{Ca}$ & $0.17 \mathrm{Cb}$ & $0.13 \mathrm{Bc}$ \\
\hline Monocropped Paiaguas palisadegrass & $0.43 \mathrm{Aa}$ & $0.31 \mathrm{Ab}$ & $0.23 \mathrm{Ac}$ \\
\hline Row corn $\times$ Paiaguas palisadegrass & $0.34 \mathrm{Ba}$ & $0.29 \mathrm{Ba}$ & $0.17 \mathrm{Bc}$ \\
\hline Inter-row corn $\times$ Paiaguas palisadegrass & $0.35 \mathrm{Ba}$ & $0.27 \mathrm{Bb}$ & $0.18 \mathrm{Bc}$ \\
\hline Oversown corn $\times$ Paiaguas palisadegrass & $0.28 \mathrm{BCa}$ & $0.21 \mathrm{Bb}$ & $0.14 \mathrm{Bc}$ \\
\hline CV (\%) & & 16.33 & \\
\hline P-value (forage system) & & 0.0024 & \\
\hline P-value (maturity stage) & & 0.0000 & \\
\hline
\end{tabular}

Mean values followed by different uppercase letters in the same column (forage systems) and lowercase letters in the same row (maturity stages) are significantly different by Tukey's test at 5\% probability. 
Table 6 - Content of neutral and acid detergent fiber and lignin of silages in different forage systems and maturity stage of corn

\begin{tabular}{|c|c|c|c|}
\hline \multirow{2}{*}{ Forage system } & \multicolumn{3}{|c|}{ Maturity stage } \\
\hline & Milky & Soft dough & Hard dough \\
\hline & \multicolumn{3}{|c|}{ Neutral detergent fiber $\left(\mathrm{g} \mathrm{kg}^{-1}\right)$} \\
\hline Monocropped corn & $585.54 \mathrm{Cb}$ & $633.16 \mathrm{Ca}$ & $642.57 \mathrm{Ca}$ \\
\hline Monocropped Paiaguas palisadegrass & $685.58 \mathrm{Ab}$ & 703.66Aa & $734.20 \mathrm{Aa}$ \\
\hline Row corn $\times$ Paiaguas palisadegrass & $665.04 \mathrm{Bb}$ & 678.63Ва & $682.38 \mathrm{Ba}$ \\
\hline Inter-row corn $\times$ Paiaguas palisadegrass & $642.25 \mathrm{Bb}$ & 681.72Ba & $698.00 \mathrm{Ba}$ \\
\hline Oversown corn $\times$ Paiaguas palisadegrass & $623.59 \mathrm{Bb}$ & 668.19BCa & 698.17Bab \\
\hline $\mathrm{CV}(\%)$ & & 3.28 & \\
\hline P-value (forage system) & & 0.0000 & \\
\hline \multirow[t]{2}{*}{ P-value (maturity stage) } & & 0.0002 & \\
\hline & \multicolumn{3}{|c|}{ Acid detergent fiber $\left(\mathrm{g} \mathrm{kg}^{-1}\right)$} \\
\hline Monocropped corn & $345.21 \mathrm{Cb}$ & $369.20 \mathrm{Ca}$ & $372.71 \mathrm{Ca}$ \\
\hline Monocropped Paiaguas palisadegrass & $393.17 \mathrm{Ab}$ & $439.62 \mathrm{Aa}$ & 446.90 Aа \\
\hline Row corn $\times$ Paiaguas palisadegrass & $378.23 \mathrm{Bb}$ & $394.18 \mathrm{Ba}$ & 408.60Ba \\
\hline Inter-row corn $\times$ Paiaguas palisadegrass & $374.88 \mathrm{Bb}$ & $396.42 \mathrm{Ba}$ & $403.77 \mathrm{Ba}$ \\
\hline Oversown corn $\times$ Paiaguas palisadegrass & $370.49 \mathrm{Bb}$ & $369.27 \mathrm{Ba}$ & 398.06Ba \\
\hline CV (\%) & & 4.67 & \\
\hline P-value (forage system) & & 0.0000 & \\
\hline \multirow[t]{2}{*}{ P-value (maturity stage) } & & 0.0032 & \\
\hline & \multicolumn{3}{|c|}{$\operatorname{Lignin}\left(\mathrm{g} \mathrm{kg}^{-1}\right)$} \\
\hline Monocropped corn & $32.69 \mathrm{Bb}$ & $37.69 \mathrm{Ba}$ & $40.82 \mathrm{Ba}$ \\
\hline Monocropped Paiaguas palisadegrass & $60.05 \mathrm{Ab}$ & 73.34Aa & $75.23 \mathrm{Aa}$ \\
\hline Row corn $\times$ Paiaguas palisadegrass & $43.33 \mathrm{Bb}$ & $46.64 \mathrm{Ba}$ & $48.31 \mathrm{Ba}$ \\
\hline Inter-row corn $\times$ Paiaguas palisadegrass & $40.47 \mathrm{Bb}$ & $45.66 \mathrm{Ba}$ & 47.77Ba \\
\hline Oversown corn $\times$ Paiaguas palisadegrass & $36.68 \mathrm{Bb}$ & $41.71 \mathrm{Ba}$ & $43.68 \mathrm{Ba}$ \\
\hline CV (\%) & & 12.88 & \\
\hline P-value (forage system) & & 0.0000 & \\
\hline P-value (maturity stage) & & 0.0367 & \\
\hline
\end{tabular}

Mean values followed by different uppercase letters in the same column (forage systems) and lowercase letters in the same row (maturity stages) are significantly different by Tukey's test at $5 \%$ probability.

\section{Discussion}

The greatest DM production obtained in the corn intercropped with Paiaguas palisadegrass in the row and inter-row shows that these modes of sowing contributed to increase the production of the ensiled mass, increasing the yield per area. This result can be attributed to less competition of plants for water, light, nutrients, and physical space in this sowing method. For the maturity stages, the greater production of DM in the hard dough stage is due to the longer development cycle of the crop, accumulating greater DM production.

It is important to emphasize that the intercropping of corn with Paiaguas palisadegrass in the row and inter-row in all maturity stages contributed to increase silage mass production in relation to silage in monocropping, showing the benefits of producing silage in the crop-livestock integration system. Similar results were obtained by Pariz et al. (2017), who evaluated corn intercropped with Marandu palisadegrass, which, compared with monocropped corn, especially at the cutting height of $0.45 \mathrm{~m}$, is a viable option for improving silage and pasture production, as well as land use efficiency in the integrated crop-livestock system.

The greatest buffering capacity of the silage of monocropped Paiaguas palisadegrass in all maturity stages (Table 4) is because forage grasses present greater buffering capacity at the time of cutting, 
making it difficult to lower the $\mathrm{pH}$ of the silage by the resistance of the forage mass, which is a key factor in the fermentation process. The ability of the plant to grow depends on the plant composition regarding crude protein concentration, inorganic ions (calcium, potassium, and sodium), and the combination of organic acids and their salts (Jobim et al., 2007). When the plant presents a great buffering capacity, the $\mathrm{pH}$ drop velocity is slow and, consequently, the losses in the silage process are greater, reducing the silage quality (Cherney and Cherney, 2003).

The reduction in the buffering capacity in silages of the intercropping systems is related to the greater proportion of corn in the silage (Table 1), and this certainly provided a better quality to the silage, since it allows the fermentation to occur properly. The greater the buffering capacity, the lower the

Table 7 - Content of crude protein, total digestible nutrients, ether extract, and in vitro dry matter digestibility of silages in different forage systems and maturity stage of corn

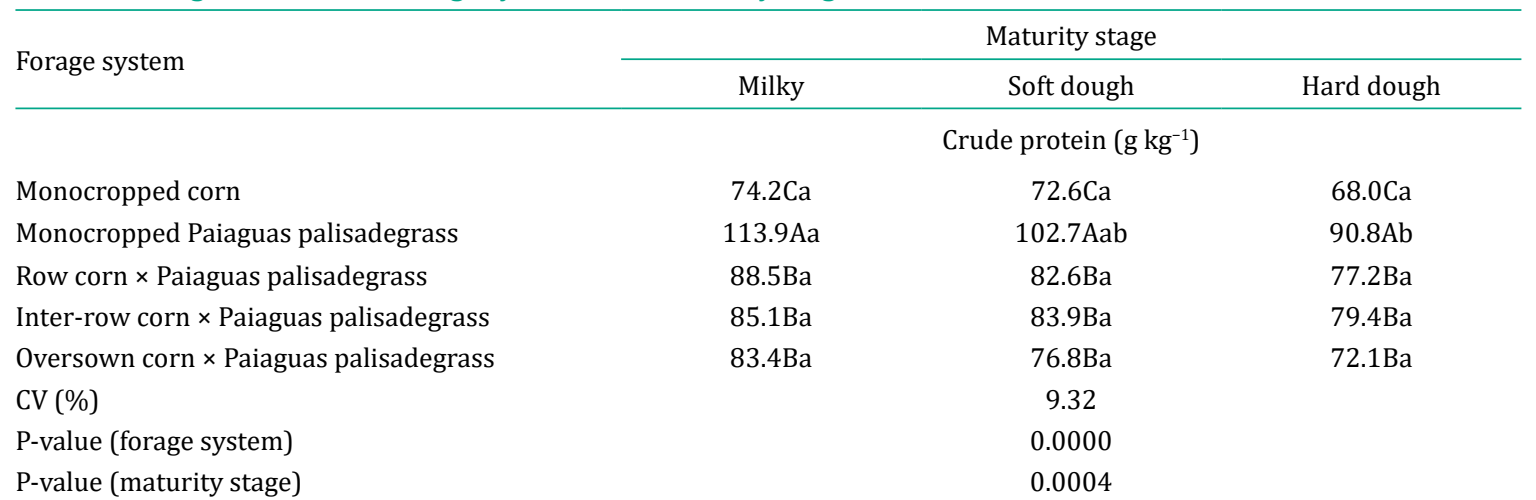

Monocropped corn

Monocropped Paiaguas palisadegrass

Row corn $\times$ Paiaguas palisadegrass

Inter-row corn $\times$ Paiaguas palisadegrass

Oversown corn $\times$ Paiaguas palisadegrass

$\mathrm{CV}(\%)$

P-value (forage system)

P-value (maturity stage)

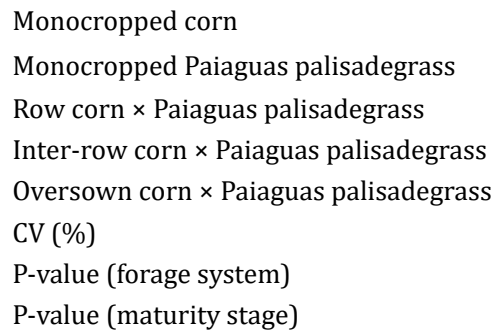

Monocropped corn

Monocropped Paiaguas palisadegrass

Row corn $\times$ Paiaguas palisadegrass

Inter-row corn $\times$ Paiaguas palisadegrass

Oversown corn $\times$ Paiaguas palisadegrass

CV (\%)

P-value (forage system)

P-value (maturity stage)
41.92Aa

$21.91 \mathrm{Ca}$

31.28Ba

33.12Ba

38.43Ba

Ether extract $\left(\mathrm{g} \mathrm{kg}^{-1}\right)$

$$
\begin{gathered}
42.92 \mathrm{Aa} \\
22.56 \mathrm{Ca} \\
34.28 \mathrm{Ba} \\
35.12 \mathrm{Ba} \\
39.93 \mathrm{Ba} \\
11.24 \\
0.0000 \\
0.0077
\end{gathered}
$$

Total digestible nutrients $\left(\mathrm{g} \mathrm{kg}^{-1}\right)$

$\begin{array}{ccc}700.03 \mathrm{Aa} & 723.32 \mathrm{Aa} & 713.36 \mathrm{Aa} \\ 573.39 \mathrm{Ca} & 540.09 \mathrm{Ca} & 546.67 \mathrm{Ca} \\ 656.66 \mathrm{Ba} & 673.38 \mathrm{Ba} & 640.05 \mathrm{Ba} \\ 650.09 \mathrm{Ba} & 676.65 \mathrm{Ba} & 633.37 \mathrm{Ba} \\ 673.3 \mathrm{ABa} & 686.63 \mathrm{ABa} & 686.60 \mathrm{ABa} \\ & 2.57 & \\ & 0.0000 & \\ & 0.0453 & \\ & & \\ & \text { In vitro dry matter digestibility }\left(\mathrm{g} \mathrm{kg}^{-1}\right) \\ 705.14 \mathrm{Ab} & 734.85 \mathrm{Aab} & 512.93 \mathrm{Ca} \\ 548.43 \mathrm{Ca} & 521.92 \mathrm{Ca} & 702.66 \mathrm{Ba} \\ 649.40 \mathrm{Bb} & 684.49 \mathrm{Bab} & 709.81 \mathrm{Ba} \\ 665.39 \mathrm{Bb} & 695.13 \mathrm{Bab} & 712.99 \mathrm{Ba} \\ 685.16 \mathrm{Bb} & 700.29 \mathrm{Bab} & \\ & 4.54 & \\ & 0.0000 & \end{array}$

Mean values followed by different uppercase letters in the same column (forage systems) and lowercase letters in the same row (maturity stages) are significantly different by Tukey's test at $5 \%$ probability.
44.92Aa

22.98Ca

36.28Ba

$36.12 \mathrm{Ba}$

40.43Ba

$546.67 \mathrm{Ca}$

$6.60 \mathrm{ABa}$

81.95Aa

$12.93 \mathrm{Ca}$

$2.99 \mathrm{Ba}$ 
amount of acid required to reduce the $\mathrm{pH}$ of the silage, the faster the fermentation process, the lower the soluble carbohydrate, and the smaller will be the losses. On the fermentative characteristics of Piata palisadegrass ensiled with energetic meals, Perim et al. (2014) reported lower buffering capacity with corn meal, and these results were similar to those obtained in this study.

In the maturity stages, there was a reduction in buffering capacity at the hard dough stage for monocropped and intercropped corn. This result is due to the greater contribution from soluble carbohydrates with the maturity of corn grains, which accumulates more reserve carbohydrates, such as starch and berries. Soluble carbohydrates are basic nutrients for fermentation by the microorganisms involved in the ensiling process, since the levels of ammonia nitrogen and $\mathrm{pH}$ of the silage are kept low (McDonald et al., 1991). These sugars are used by bacteria as substrates for fermentation, producing organic acids, mainly lactic acid, resulting in the acidification of the medium and, consequently, improving the conservation of silage. According to McDonald et al. (1991), the minimum value of soluble carbohydrates required to ensure lactic fermentation of the silages should be $60-80 \mathrm{~g} \mathrm{~kg}^{-1} \mathrm{DM}$.

In general, the buffering capacity values found in silages of monocropped and intercropped corn were within the range recommended by the literature; therefore, it is not a barrier to the rapid drop of $\mathrm{pH}$. Values below 20 eq.mg $\mathrm{HCl} \mathrm{g}^{-1} \mathrm{DM}$ are considered as ideal for obtaining quality silage (Ferrari Júnior and Lavezzo, 2001).

Greater $\mathrm{pH}$ values obtained in silages of monocropped Paiaguas palisadegrass in all forage systems and maturity stages (Table 4) are associated with the greater buffering capacity of tropical grass silages, as observed in the present study, which consequently may lead to undesirable fermentations.

In the Paiaguas palisadegrass silage, the greatest $\mathrm{pH}$ was observed in the milky stage of corn; thus, it can be inferred that when ensiled at early vegetative development stages, the forage has a lower DM concentration, correlating directly with a greater $\mathrm{pH}$ value. In addition, the lower DM concentration will negatively influence the fermentation process, preventing the rapid $\mathrm{pH}$ decrease, facilitating the occurrence of undesirable secondary fermentation, due to the presence of butyric acid in proportions equal to or greater than $0.1 \%$, which may lead to losses in the quality of the final product (McDonald et al., 1991).

Nevertheless, for monocropped and intercropped corn, the $\mathrm{pH}$ values were similar between maturity stages, being close to those reported by Leonel et al. (2008), who recorded $\mathrm{pH}$ of 3.51 at 100 days after planting in silages of corn intercropped with Brachiaria brizantha cv. MG-5.

For a silage to be considered of good quality, it is necessary to have $\mathrm{pH}$ values between 3.8 and 4.2, because at this range, the proteolytic enzymes of the plant enterobacteria and clostridia are sufficiently restricted to preserve the material analyzed (Tomich et al., 2004).

Nevertheless, only the silage of monocropped Paiaguas palisadegrass presented $\mathrm{pH}$ greater than 4.2 and, thus, greater than the values recommended for a good fermentation in all maturity stages (Tomich et al., 2004). This emphasizes the importance of producing silage from annual crops with forage, intercropped, to guarantee the reduction of $\mathrm{pH}$ in the silages, which is essential for the conservation of the ensiled product. However, the $\mathrm{pH}$ value of the silage should not be considered isolatedly as a criterion for the classification of fermentation.

Reductions in $\mathrm{NH}_{3}-\mathrm{N}$ concentration in silage of monocropped and intercropped corn are due to the fact that corn has greater concentration of soluble carbohydrates, which are readily available for fermentation. However, it is verified that the mean values of $\mathrm{NH}_{3}-\mathrm{N}$ of the silages of all forage systems remained below $100 \mathrm{~g} \mathrm{~kg}^{-1}$, providing proper lactic fermentation, consequently reducing proteolysis and inhibiting undesirable microorganisms (Kung and Shaver, 2001).

In relation to the maturity stages, the Paiaguas palisadegrass silage harvested at the milky stage of corn showed the greatest value of $\mathrm{NH}_{3}-\mathrm{N}$, which can be explained by the lower $\mathrm{DM}$ concentration when compared with the hard dough stage. 
The lowest concentration of DM in the silage of monocropped Paiaguas palisadegrass in all maturity stages (Table 4) may be explained as described by Bergamaschine et al. (2006), who reported that tropical grasses do not present adequate DM levels, buffering capacity, and soluble carbohydrates, which provide an ideal fermentation process in the Marandu palisadegrass silage. In general, the silage of monocropped Paiaguas palisadegrass presented DM concentration below the ideal range. These DM values can provide favorable conditions for the appearance of aerobic microorganisms, yeasts, and fungi, promoting losses in the nutritive value of silages.

Silages of all forage systems, with the advancement of maturity stages, undergo morphological changes in the DM concentration, which allow to check, in a simple way, the most appropriate moment to the ensiling process. It is observed that at the hard dough stage, silages of monocropped or intercropped corn presented adequate DM concentration according to Marafon et al. (2015), who recommends the ensiling of corn at later maturity stages, when it presents from 300 to $350 \mathrm{~g} \mathrm{~kg}^{-1} \mathrm{DM}$.

Hence, it is possible to affirm that intercropping can be an effective tool in minimizing the undesirable characteristics of the fermentative processes of tropical grass silages, besides enabling the substitution of exclusive corn silages, and allowing to reduce the production costs in the ensiling process with the increase in mass yield (Table 3) through forage.

Among the organic acids (acetic, propionic, butyric, and lactic) that contribute to the final acidity of the stored mass, lactic acid, due to its greater dissociation constant $(\mathrm{pKa}=3.86)$, that is, a greater tendency to lose protons (Lehninger et al., 2002), plays a key role in the fermentation process of silage, since it is responsible for the $\mathrm{pH}$ drop below 4.20. At this $\mathrm{pH}$ value, there is inhibition of Clostridium bacteria, responsible for undesirable fermentations in the product (Carvalho et al., 2016).

The silage of monocropped Paiaguas palisadegrass had the lowest concentration of lactic acid, with a mean value of $19.8 \mathrm{~g} \mathrm{~kg}^{-1}$ (Table 5). This result is similar to those reported by Cezário et al. (2015), in which the average concentration of lactic acid was $19.7 \mathrm{~g} \mathrm{~kg}^{-1}$ for Marandu palisadegrass silage. Thus, it is worth mentioning that, when compared with other forage systems, the lower concentration of lactic acid resulted in greater $\mathrm{pH}$ values of Paiaguas palisadegrass silage (Table 4).

Greater concentration of lactic acid observed in monocropped corn silage followed by silages of the intercropping systems evidenced the benefits of intercropping corn with Paiaguas palisadegrass for silage production, regardless of the sowing method, once the intercropped silages presented superior lactic acid values than the silage of monocropped Paiaguas palisadegrass.

In general, the extent of amino acid degradation in low $\mathrm{pH}$ silages depends mainly on the degree to which clostridic activity has been suppressed, and this is related to the rate of lactic acid production and consequent drop in pH (Rabelo et al., 2014), corroborating the results in the present study for monocropped corn silage. In grass silages, using the classification criteria established by Roth and Undersander (1995), values of lactic acid in the $40-60 \mathrm{~g} \mathrm{~kg}^{-1}$ range are considered of good quality.

With respect to maturity stages, greater concentrations of lactic acid were obtained at the hard dough stage in silages of monocropped and intercropped corn (Table 5). These results are due to the greater concentration of soluble carbohydrates. Johnson et al. (2001) and Filya and Sucu (2010) reported that the greater concentration of soluble carbohydrates available in cereal grains allows a rapid acidification of the ensiled mass. Further, a satisfactory population of bacteria, mainly of the genus Lactobacillus, is the major responsible for the production of lactic acid, because the acidolatic bacteria are the main group of microorganisms that act on the fermentation process to preserve the ensiled mass and produce mainly lactic acid as a product of sugarcane fermentation (McDonald et al., 1991).

Although the silage of monocropped Paiaguas palisadegrass presented the greatest concentration of acetic, propionic, and butyric acids compared with monocropped and intercropped corn silage, the concentrations of acetic acid are within the range recommended by the literature, with adequate concentrations, lower than the limit of $20.0 \mathrm{~g} \mathrm{~kg}^{-1}$, which, according to Roth and Undersander (1995), is the threshold to classify silages as good quality. According to the authors, high acetic acid values indicate undesirable changes during lactic fermentation. 
Concentrations above $5.0 \mathrm{~g} \mathrm{~kg}^{-1}$ of propionic acid means the degradation of lactic acid by butyric bacteria (Kung and Shaver, 2001). In this sense, in the present study, the values found in all forage systems did not affect the stability of the silages. For the concentration of butyric acid, according to Vieira et al. (2004), values are considered as adequate when less than $1.0 \mathrm{~g} \mathrm{~kg}^{-1} \mathrm{DM}$. Thus, due to lower values than recommended, the silages have fermentation adequate to preserve the ensiled mass. The predominance of lactic acid concentration was probably the factor that contributed to the production of well preserved silages, due to its important role in inhibiting the action of clostridia.

The lowest concentrations of propionic and butyric acids at the hard dough stage in all forage systems are related to the greater DM concentration at the time of cutting (Table 3), because when there is excess moisture, the conditions are favorable to obtain butyric acid, obtaining a silage of low quality, which may contribute to reduce the nutritive value of the preserved mass. Anaerobic bacteria of the genus Clostridium have a negative effect on silage quality, especially if the $\mathrm{pH}$ is not low enough to inhibit their growth (McDonald et al., 1991).

Lower NDF and ADF concentration (Table 6) obtained in monocropped corn silage, followed by the silages of the intercropping systems, demonstrate the advantage of producing silage in intercropping systems, where it is verified that corn intercropped with Paiaguas palisadegrass in the different sowing method contributed to reduce the NDF and ADF concentration compared with the silage of monocropped Paiaguas palisadegrass, with dilution of the fiber fraction.

These results corroborate Leonel et al. (2008), in which the mean NDF values of the silage of Brachiaria brizantha $\mathrm{cv}$. MG-5 grown exclusively were greater than the silage concentrations of the intercropping systems. Probably, the lowest NDF values of the silages of the intercropping systems are related to the presence of ears of corn plants. Additionally, considering that the silages of grasses have a great concentration of fiber carbohydrates, which cause slow digestion in the rumen, and that the protein sources are rapidly degraded, it can be inferred that it is necessary to synchronize carbohydrates and proteins in the diet to ensure microbial efficiency. Thus, the greatest concentration of NDF and ADF were obtained in silage of monocropped Paiaguas palisadegrass, possibly negatively affecting intake by rumen fill and, therefore, the performance of the animals (Mertens, 1987).

Greater increase in NDF and ADF concentrations in all forage systems at the soft dough and hard dough stages of corn (Table 6) is due to the maturity of forages, harvested in longer cycles. Evaluating the silage of Marandu palisadegrass, Prado et al. (2013) verified NDF concentrations ranging from 689.90 to $727.55 \mathrm{~g} \mathrm{~kg}^{-1}$, values similar to those observed in the present study between the milky and hard dough stages.

The greatest lignin concentration in silages of monocropped Paiaguas palisadegrass (Table 6) is probably due to the greater fiber fractions of the grass. Figueredo et al. (2014) observed lignin concentrations of $49.12 \mathrm{~g} \mathrm{~kg}^{-1}$ in silages of Piata palisadegrass in the exclusive form, but in the present study, values were above this level, with a mean value of $69.54 \mathrm{~g} \mathrm{~kg}^{-1}$. Thus, these great concentration may limit the digestion of some tissues, not only by the negative effect of lignin on the digestion of cell wall components, but also by the arrangement of cells and by the large cell wall thickness (Oliveira et al., 2010).

The mean lignin values in the corn silages at the hard dough stage obtained in this study corroborate those reported in the literature. In the evaluation of corn silage, Silva et al. (2005) observed a mean value of $42.00 \mathrm{~g} \mathrm{~kg}^{-1}$, and Leonel et al. (2008) in Brachiaria brizantha cv. MG-5 intercropped with two rows between the rows of corn, verified a lignin concentration of $46.80 \mathrm{~g} \mathrm{~kg}^{-1}$.

The lowest CP concentrations obtained in monocropped corn silages, followed by the intercropping systems, in all maturity stages (Table 7), are associated with the greater proportion of corn in the ensiled material (Table 1). These concentrations corroborate those reported by Silva et al. (2005) of $76.8 \mathrm{~g} \mathrm{~kg}^{-1} \mathrm{CP}$ in DM in exclusive corn silage. It shows that it is advantageous to use the intercropping system, since the $\mathrm{CP}$ concentration was greater than in corn silage, which is considered standard by the producers.

R. Bras. Zootec., 48:e20180222, 2019 
In the soft dough and dough maturity stages of corn, in the silage of monocropped Paiaguas palisadegrass, there was a reduction in CP concentration. In an advanced phenological stage, the grass, due to its production cycle, decreases $\mathrm{CP}$ concentration compared with its initial stages, due to stem lignification (Leonel et al., 2009).

Except for monocropped corn silage in the hard dough stage, the silage of monocropped and intercropped Paiaguas palisadegrass showed values greater than $70 \mathrm{~g} \mathrm{~kg}^{-1} \mathrm{CP}$, that is, above the limit reported by Lazzarini et al. (2009) as a minimum to maintain the population of bovine rumen microorganisms, without compromising the efficient utilization of fiber carbohydrates of the silages. It is worth mentioning the importance of producing corn silage with Paiaguas palisadegrass due to the significant increase in CP concentration of silages compared with the monocropped corn silage, once crude protein is considered the most expensive ingredient in animal diets.

Paiaguas palisadegrass is a forage that has high leaf blade:stem ratio and is now considered a cultivar of great importance in the crop-livestock integration system, for presenting regrowth in the dry period of the year, with greater accumulation of forage of better nutritive value (Costa et al., 2018).

Several studies have evidenced the benefits of producing silages from intercropping systems. Ribeiro et al. (2017) stated that silages from intercropping systems ensure fermentation and nutritional quality, providing interesting supplementary bulky options to be used in the off-season for feeding animals. Cruvinel et al. (2017) argued that silages with 30\% Piata and Paiaguas palisadegrass showed greater $\mathrm{CP}$ concentration and lower ADF and lignin levels, and these cultivars are the most recommended for ensiling with sunflower.

Greater EE concentration in monocropped corn silage (Table 7) is due to the greater amount of EE in the corn grains, demonstrating that the association of crops assists to balance the energy value of silages, being an important factor in ruminal fermentation, fiber digestibility and, consequently, in the rate of passage (NRC, 2001). The mean EE value of $48.38 \mathrm{~g} \mathrm{~kg}^{-1}$ in the monocropped corn silage corroborates that obtained by Carvalho et al. (2016) of $45.60 \mathrm{~g} \mathrm{~kg}^{-1}$.

The lowest TDN concentration values obtained in monocropped Paiaguas palisadegrass silage in all maturity stages (Table 7) are a consequence of the lower EE concentration contained in the Paiaguas palisadegrass silage (Table 1), which contributed to decrease the energy of the feed, knowing that the EE concentration provides 2.25 times more energy than carbohydrate. In this way, the advantage of using intercropping systems is evident, since TDN concentration were greater in these systems at all maturity stages.

Similar TDN concentration in the silage of monocropped Paiaguas palisadegrass was observed in silages of two cultivars of Brachiaria, Mulatto and Marandu: 561 and $545 \mathrm{~g} \mathrm{~kg}^{-1}$, respectively (Pariz et al., 2010). In addition, according to Oliveira et al. (2010), TDN is an essential variable, because energy and protein are usually the most limiting factors for ruminants.

Greater IVDMD values verified in monocropped corn silage followed by the intercropping systems demonstrate the contribution of corn to improve silage quality in systems intercropped with grass. Van Soest (1994) reported elevation in IVDMD with the addition of material containing a greater concentration of non-structural carbohydrates, which are more digestible than the structural carbohydrates (Krämer-Schmid et al., 2016), which can justify the greater IVDMD values in monocropped and intercropped corn silages compared with monocropped Paiaguas palisadegrass. As verified in monocropped Paiaguas palisadegrass, greater of NDF and ADF values (Table 6) were obtained, consequently associated with lower IVDMD.

The IVDMD values of monocropped corn silage were close to those obtained by Carvalho et al. (2016) and Domingues et al. (2012), who analyzed monocropped corn silages supplemented with forage peanuts and silages of different corn hybrids in the off-season and observed mean digestibility values of 746.71 and $707.90 \mathrm{~g} \mathrm{~kg}^{-1}$, respectively. In contrast, Serbester et al. (2015) reported a lower digestibility (606.53 $\left.\mathrm{g} \mathrm{kg}^{-1}\right)$ in monocropped corn silage.

R. Bras. Zootec., 48:e20180222, 2019 


\section{Conclusions}

Silage of corn intercropped with Paiaguas palisadegrass in the row and inter-row at the hard dough stage showed greater productivity per area and better fermentative and nutritional characteristics. They can, therefore, be recommended as suitable sowing systems for silage production.

Silages produced from intercropping systems proved to be an alternative feed supply technique, allowing the intensification of production systems, maximizing nutrient production per area in a sustainable manner.

\section{Conflict of Interest}

The authors declare no conflict of interest.

\section{Author Contributions}

Formal analysis: A. Guarnieri, J.T. Silva, D.A.A. Teixeira, S.S. Oliveira and M.B.C. Dias. Methodology: A. Guarnieri, J.T. Silva, D.A.A. Teixeira, S.S. Oliveira and M.B.C. Dias. Software: E.C. Severiano. Supervision: W.F. Souza and K.A.P. Costa. Writing-original draft: W.F. Souza and A. Guarnieri. Writing-review \& editing: K.A.P. Costa.

\section{Acknowledgments}

The authors would like to thank the Instituto Federal Goiano for supporting this study.

\section{References}

AOAC - Association of Analytical Communities. 1990. Official methods of analysis. 15th ed. Association Official Analytical Chemists, Arlington, VA.

Bergamaschine, A. F; Passipiéri, M.; Veriano Filho, W. V.; Isepon, O. J. and Correa, L. A. 2006. Qualidade e valor nutritivo de silagens de capim-marandu (B. brizantha cv. Marandu) produzidas com aditivos ou forragem emurchecida. Revista Brasileira de Zootecnia 35:1454-1462. https://doi.org/10.1590/S1516-35982006000500027

Bolsen, K. K.; Lin, C.; Brent, B. E.; Feyerherm, A. M.; Urban, J. E. and Aimutis, W. R. 1992. Effect of silage additives on the microbial succession and fermentation process of alfalfa and corn silages. Journal of Dairy Science 75:3066-3083. https://doi.org/10.3168/jds.S0022-0302(92)78070-9

Carvalho, A. F. G.; Martin, T. N.; Santos, S.; Muller, T. M. and Piran Filho, F. A. 2016. Perfil agronômico e bromatológico de silagem de milho no sudoeste do Paraná. Revista de la Facultad de Agronomía, La Plata 114:149-159.

Cezário, A. S.; Ribeiro, K. G.; Santos, S. A.; Valadares Filho, S. C. and Pereira, O. G. 2015. Silages of Brachiaria brizantha cv. Marandu harvested at two regrowth ages: microbial inoculant responses in silage fermentation, ruminant digestion and beef cattle performance. Animal Feed Science and Technology 208:33-43. https://doi.org/10.1016/j.anifeedsci.2015.06.025

Chandler, P. 1990. Energy prediction offeedsby forage testing explorer. Feedstuffs 62:1-12.

Cherney, J. H. and Cherney, D. J. R. 2003. Assessing silage quality. p.141-198. In: Silage science and technology. Buxton, D. R.; Muck, R. E. and Harrison, J. H., eds. Madison, Wisconsin, USA.

Costa, K. A. P.; Assis, R. L.; Guimarães, K. C.; Severiano, E. C.; Assis Neto, J. M.; Cruvinel, W. S.; Garcia, J. F. and Santos, N. F. 2011. Silage quality of Brachiaria brizantha cultivars ensiled with different levels of millet meal. Arquivo Brasileiro de Medicina Veterinária e Zootecnia 63:188-195. https://doi.org/10.1590/S0102-09352011000100028

Costa, R. R. G. F.; Costa, K. A. P.; Souza, W. F.; Epifanio, P. S.; Santos, C. B.; Silva, J. T. and Oliveira, S. S. 2018. Production and quality of silages pearl millet and Paiaguas palisadegrass in monocropping and intercropping in different forage systems. Bioscience Journal 34:357-367. https://doi.org/10.14393/BJ-v34n2a2018-33843

Cruvinel, W. S.; Costa, K. A. P.; Teixeira, D. A. A.; Da Silva, J. T.; Epifanio, P. S.; Costa, P. H. C. P. and Fernandes, P. B. 2017. Fermentation profile and nutritional value of sunflower silage with Urochloa brizantha cultivars in the off-season. Revista Brasileira de Saúde e Produção Animal 18:249-259. https://doi.org/10.1590/s1519-99402017000200004

Domingues, N. A.; Abreu, J. G.; Cabral, L. S.; Galati, R. L.; Oliveira, M. A. and Reis, R. H. P. 2012. Nutrition value of silage from corn hybrids in the State of Mato Grosso, Brazil. Acta Scientiarum. Animal Sciences 34:117-122. https://doi.org/10.4025/ actascianimsci.v34i2.11782 
EMBRAPA - Empresa Brasileira de Pesquisa Agropecuária. 2016. Dia de Campo mostra a versatilidade dos sistemas de integração aos participantes do Congresso Mundial sobre ILPF. Available at: <https://www.embrapa.br/busca-denoticias/-/noticia/3669566/dia-de-campo-mostra-a-versatilidade-dos-sistemas-de-integracao-aos-participantes-docongresso-mundial-sobre-ilpf>. Accessed on: Oct. 12, 2016.

Epifanio, P. S.; Costa, K. A. P.; Severiano, E. C.; Cruvinel, W. S.; Bento, J. C. and Perim, R. C. 2014. Fermentative and bromatological characteristics of Piata palisadegrass ensiled with levels of meals from biodiesel industry. Semina: Ciências Agrárias 35:491-504. https://doi.org/10.5433/1679-0359.2014v35n1p491

Euclides, V. P. B.; Montagner, D. B.; Barbosa, R. A.; Valle, C. B. and Nantes, N. N. 2016. Animal performance and sward characteristics of two cultivars of Brachiaria brizantha (BRS Paiaguás and BRS Piatã). Revista Brasileira de Zootecnia 45:85-92. https://doi.org/10.1590/S1806-92902016000300001

Ferrari Júnior, E. and Lavezzo, W. 2001. Qualidade da silagem de capim-elefante (Pennisetum purpureum Schum.) emurchecido ou acrescido de farelo de mandioca. Revista Brasileira de Zootecnia 30:1424-1431. https://doi.org/10.1590/ S1516-35982001000600006

Ferreira, E. B.; Cavalcanti, P. P. and Nogueira, D. A. 2014. ExpDes: An R Package for ANOVA and experimental designs. Applied Mathematics 5:2952-2958. https://doi.org/10.4236/am.2014.519280

Figueredo, R. S.; Costa, K. A. P.; Epifanio, P. S.; Severiano, E. C.; Cruvinel, W. S.; Moreira, T. S. and Guimarães, K. C. 2014. Silage quality of Piata palisadegrass with palm kernel cake. Semina: Ciências Agrárias 35:505-518. https://doi. org/10.5433/1679-0359.2014v35n1p505

Filya, I. and Sucu, E. 2010. The effects of lactic acid bacteria on the fermentation, aerobic stability and nutritive value of maize silage. Grass Forage Science 65:446-455. https://doi.org/10.1111/j.1365-2494.2010.00763.x

Garcia, C. M. P.; Andreotti, M.; Teixeira Filho, M. C. M.; Buzetti, S.; Celestrino, T. S. and Lopes, K. S. M. 2013. Desempenho agronômico da cultura do milho e espécies forrageiras em sistema de Integração Lavoura-Pecuária no Cerrado. Ciência Rural 43:589-595. https://doi.org/10.1590/S0103-84782013000400005

Jobim, C. C.; Nussio, L. G.; Reis, R. A. and Schmidt, P. 2007. Avanços metodológicos na avaliação da qualidade da forragem conservada. Revista Brasilera de Zootecnia 36:101-119. https://doi.org/10.1590/S1516-35982007001000013

Johnson, L. M.; Harrison, J. H.; Davidson, D.; Mahanna, W. C.; Shinners, K. and Linder, D. 2001. Com silage management: Effects of maturity, inoculation, and mechanical processing on pack density and aerobic stability. Journal of Dairy Science 85:434-444. https://doi.org/10.3168/jds.S0022-0302(02)74092-7

Krämer-Schmid, M.; Lund, P. and Weisbjerg, M. R. 2016. Importance of NDF digestibility of whole crop maize silage for dry matter intake and milk production in dairy cows. Animal Feed Science and Technology 219:68-76. https://doi. org/10.1016/j.anifeedsci.2016.06.007

Kung, L. and Shaver, R. 2001. Interpretation and use of silage fermentation analysis reports. Focus on Forage 3:1-5.

Lazzarini, I.; Detmann, E.; Sampaio, C. B.; Paulino, M. F.; Valadares Filho, S. C.; Souza, M. A. and Oliveira, F. A. 2009. Dinâmicas de trânsito e degradação da fibra em detergente neutro em bovinos alimentados com forragem tropical de baixa qualidade e compostos nitrogenados. Arquivo Brasileiro de Medicina Veterinária e Zootecnia 61:635-647. https://doi.org/10.1590/S0102-09352009000300017

Lehninger, A. L.; Nelson, D. L. and Cox, M. M. 2002. Princípios de bioquímica. 3.ed. Savier, São Paulo, SP.

Leonel, F. P.; Pereira, J. C.; Costa, M. G.; Marco Júnior, P.; Lara, L. A.; Ribeiro, M. D. and Silva, C. J. 2008. Consórcio capimbraquiária e milho: produtividade das culturas e características qualitativas das silagens feitas com plantas em diferentes idades. Revista Brasileira de Zootecnia 37:2233-2242. https://doi.org/10.1590/S1516-35982008001200022

Leonel, F. P.; Pereira, J. C.; Costa, M. G.; Marco Júnior, P.; Silva, C. J. and Lara, L. A. 2009. Consórcio capim-braquiária e milho: comportamento produtivo das culturas e características nutricionais e qualitativas das silagens. Revista Brasileira de Zootecnia 38:166-176. https://doi.org/10.1590/S1516-35982009000100021

Marafon, F.; Neumann, M.; Ribas, T. M. B.; Reinehr, L. L.; Poczynek, M.; Bueno, A. V. I. and Fianco, B. 2015. Análise do efeito da colheita da planta de milho em diferentes estádios reprodutivos e do processamento dos grãos sobre a qualidade da silagem. Semina: Ciências Agrárias 36:3257-3268. https://doi.org/10.5433/1679-0359.2015v36n5p3257-3268

McDonald, P.; Henderson, A. R. and Heron, S. J. E. 1991. The biochemistry of silage. 2nd ed. Chalcombe Pub., Marlow. 340p.

Mertens, D. R. 1987. Predicting intake and digestibility using mathematical models of ruminal function. Journal of Animal Science 64:1548-1558. https://doi.org/10.2527/jas1987.6451548x

Mertens, D. R. 2002. Gravimetric determination of amylase-treated neutral detergent fiber in feeds with refluxing in beaker or crucibles: collaborative study. Journal of AOAC International 85:1217-1240.

NRC - National Research Council. 2001. Nutrient requeriments of dairy cattle. 7th ed. The National Academies Press, Washington, D.C.

Oliveira, L. B.; Pires, A. J. V.; Carvalho, G. G. P.; Ribeiro, L. S. O.; Almeida, V. V. and Peixoto, C. A. M. 2010. Perdas e valor nutritivo de silagens de milho, sorgo-sudão, sorgo forrageiro e girassol. Revista Brasileira de Zootecnia 39:61-67. https://doi.org/10.1590/S1516-35982010000100008

R. Bras. Zootec., 48:e20180222, 2019 
Pariz, C. M.; Andreotii, M.; Azenha, M. V.; Bergamaschine, A. F.; Mello, L. M. M. and Lima, R. C. 2010. Massa seca e composição bromatológica de quatro espécies de braquiárias semeadas na linha ou a lanço, em consórcio com milho no sistema plantio direto na palha. Acta Scientiarum. Animal Sciences 32:147-154.

Pariz, C. M.; Costa, C.; Crusciol, C. A. C.; Meirelles, P. R. L.; Castilhos, A. M.; Andreotti, M.; Costa, N. R. and Martello, J. M. 2017. Silage production of corn intercropped with tropical forages in an integrated crop-livestock system with lambs. Pesquisa Agropecuária Brasileira 52:54-62. https://doi.org/10.1590/s0100-204x2017000100007

Perim, R. C.; Costa, K. A. P.; Epifanio, P. S.; Souza, W. F.; Francischini, R.; Teixeira, D. A. A.; Carvalho, W. G. and Santos Jr., D. R. 2014. Fermentative and bromatological characteristics of Piata Palisadegrass ensiled with energetic brans. American Journal of Plant Sciences 5:942-954. https://doi.org/10.4236/ajps.2014.57107

Prado, O. P. P.; Fernandes, D. B.; Bumbieris Junior, V. H.; Mizubuti, I. Y.; Ribeiro, E. L. A.; Massaro Junior, F. L.; Peixoto, E. L. T.; Silva, L. D. F.; Muniz, C. A. S. D. and Barbosa, M. A. F. 2013. Cinética de degradação ruminal de silagens de Brachiaria brizantha com diferentes aditivos microbianos. Semina Ciências Agrárias 34:4025-4036. https://doi.org/10.5433/16790359.2013v34n6Supl2p4025

Rabelo, C. H. S.; Rezende, A. V. D.; Rabelo, F. H. S.; Nogueira, D. A.; Senedese, S. S.; Vieira, P. D. F.; Bernardes, C. L. and Carvalho, A. 2014. Silagens de milho inoculadas microbiologicamente em diferentes estádios de maturidade: perdas fermentativas, composição bromatológica e digestibilidade in vitro. Ciência Rural 44:368-373. https://doi.org/10.1590/ S0103-84782014000200028

Ribeiro, M. G.; Costa, K. A. P.; Souza, W. F.; Cruvinel, W. S.; Silva, J. T. and Santos Junior, D. R. 2017. Silage quality of sorghum and Urochloa brizantha cultivars monocropped or intercropped in different planting systems. Acta scientiarum. Animal Sciences 39:243-250.

Roth, G. and Undersander, D. 1995. Silage additives: Corn silage production management and feeding. Madison American Society of Agronomy, Madison. p.27-29.

Santos, H. G.; Jacomine, P. K. T.; Anjos, L. H. C.; Oliveira, V. A.; Lumbreras, J. F.; Coelho, M. R.; Almeida, J. A.; Cunha, T. J. F. and Oliveira, J. B. 2013. Sistema Brasileiro de Classificação de Solos. 3.ed. Embrapa, Brasília, DF. 353p.

Santos, P. M.; Pezzopane, J. R. M.; Silva, F. A. M.; Evangelista, B. A.; Bettiol, G. M.; Lopes, T. S. S.; Marin, F. R. and Silva, S. C. 2010. Zoneamento de riscos climáticos para o consórcio milho x capim-marandu no Estado de São Paulo: períodos favoráveis para a implantação por município. Embrapa Pecuária Sudeste, São Carlos. 41p.

Serbester, U.; Akkaya, M. R.; Yucel, C. and Gorgulo, M. 2015. Comparison of yield, nutritive value, and in vitro digestibility of monocrop and intercropped corn-soybean silages cut at two maturity stages. Italian Journal of Animal Science 14:3636. https://doi.org/10.4081/ijas.2015.3636

Silva, B. C.; Pereira, O. G.; Pereira, D. H.; Garcia, R.; Valadares Filho, S. C. and Chizzotti, F. H. M. 2005. Consumo e digestibilidade aparente total dos nutrientes e ganho de peso de bovinos de corte alimentados com silagem de Brachiaria brizantha e concentrado em diferentes proporções. Revista Brasileira de Zootecnia 34:1060-1069. https://doi.org/10.1590/S151635982005000300039

Silva, D. J. and Queiroz, A. C. 2002. Análise de alimentos: métodos químicos e biológicos. 3.ed. UFV, Viçosa, MG. 235p.

Tilley, J. M. A. and Terry, R. A. 1963. A two-stage technique of the in vitro digestion of forage crops. Journal of the British Grassland Society 18:104-111. https://doi.org/10.1111/j.1365-2494.1963.tb00335.x

Tomich, T. R.; Gonçalves, L. C.; Tomich, R. G. P.; Rodrigues, J. A. S.; Borges, I. and Rodriguez, N. M. 2004. Características químicas e digestibilidade in vitro de silagens de girassol. Revista Brasileira de Zootecnia 33:1672-1682. https://doi. org/10.1590/S1516-35982004000700005

Van Soest, P. J. 1994. Nutritional ecology of the ruminant. 2nd ed. Cornell University Press, Ithaca. 476p.

Van Soest, P. J. and Robertson, J. B. 1985. Analysis of forages and fibrous foods. Cornell University, Ithaca. 202p.

Vieira, F. A. P.; Borges, I.; Stehling, C. A. V.; Gonçalves, L. C.; Coelho, S. G.; Ferreira, M. I. C. and Rodrigues, J. A. S. 2004 Qualidade de silagens de sorgo com aditivos. Arquivo Brasileiro de Medicina Veterinária e Zootecnia 56:764-772. https://doi.org/10.1590/S0102-09352004000600011 